\title{
Competition and Financial Effects between Islamic and Conventional Banking
}

\author{
WISNU MAWARDI ${ }^{1}$, MAHFUDZ MAHFUDZ ${ }^{1}$, RIO DHANI LAKSANA ${ }^{2}$, INTAN SHAFERI $^{2} *$ \\ ${ }^{1}$ Faculty Economics and Business, Diponegoro University, INDONESIA \\ ${ }^{2}$ Faculty Economics and Business, Jenderal Soedirman University, INDONESIA
}

\begin{abstract}
This study discusses a comprehensive analysis of the effect of competition and financial effects between Islamic and conventional banks. This study conducts in Asian countries i.e., Indonesia, Malaysia, Singapore, Thailand, Philippines, Brunei. The first step, introducing a descriptive study mapping that analyzes the characteristics the main among the sharia and conventional banking sectors. Then in the second step, the competitiveness level of Islamic and conventional banks is measured using the Lerner index model. The Lerner index is a model of the implications of the market power of Islamic and conventional banks on overall financial stability in Asian countries (Indonesia, Malaysia, Singapore, Thailand, Philippines, Brunei). This study also discusses the relationship between competition and performance in the banking system in Asian countries. A study of a competition in the banking industries relate the reasons. First about the level of market power and its effect of financial stability. Second about the analyze of competition that affect the performance and efficiency of banks.
\end{abstract}

Key-Words: - Islamic Banking Industry, Financial Stability, Market Strength.

Received: August 11, 2019. Revised: February 25, 2020. Re-revised: March 3, 2020.

Accepted: March 18, 2020. Published: March 31, 2020.

\section{Introduction}

Over the past five decades, Islamic banking has grown exponentially in terms of size, number of institutions and participants. This growth marks the presence of Islamic banking in more than 70 countries in the world. Both Muslims and NonMuslims recorded this growth well $[30,33]$. The accumulation of "Islamic assets" and the growth rate of Islamic banking assets over the past few decades have had a significant impact on global finance. This needs to be noted because the impacts that occur significantly make the world of Islamic banking a daunting thing [1,33] and the growth rate of Islamic banking will survive at the current level in the coming years. After identifying fundamental changes in the banking sector, the majority of conventional banks are now providing the latest additions to the Islamic banking sector in addition to their main service, namely conventional banking. Since the first modern Islamic bank was founded in 1975 in the United Arab Emirates, which was named Dubai Islamic Bank, many other countries then adopted the principles of Islamic Islamic Dubai banking Bank which was implemented in their banking system. At present, in several countries (eg Iran, Sudan and Pakistan) to form a banking system using Islamic financial principles (sharia-based financial system) which is explicitly practiced as a single mode [6]. Nevertheless, Islamic banking can coexist with conventional banking in other countries; e.g. Bahrain, Bangladesh, Egypt, Indonesia, Jordan, Malaysia. Among countries that have an Islamic banking system, Bahrain is considered a center of money in the Muslim world. The Bahrain Monetary Agency noted that Islamic bank assets had a rapid annual growth rate of $111 \%$ between 1998 and 2005 while conventional banking had an average annual growth rate of only $6 \%$. This growth rate is significant for the development of the Islamic banking system [10,33]. Interestingly, sharia-based banking has not only developed in Islamic countries lately, but it has also grown in nonMuslim countries. Islamic Bank of Britain became the first bank licensed by a non-Muslim country. In addition, globally, "Citibank, ABN Amro, Bank of America, HSBC, Standard Chartered, and Union Bank of Switzerland, have the latest additions to the Sharia Banking company line or offer Islamic financial products to their customers" $[33,48]$. 
With the rapid growth of Islamic banks, various arguments have arisen which try to clarify these significant developments. Some argue that what triggered this growth was the rise of Islam throughout the world since the late 1960s. While other arguments argue that sensitivity factors to religion such as religious beliefs, interest restrictions, costs and benefits offered by banks, banking efficiency, location, service quality, and others affect customers to use Islamic banking. This has led to the rapid growth of Islamic banking. $[50,40]$ suggest that the only factor that often arises where customers become motivated to decide on their choice of Islamic Banking is a sensitivity factor to religion or a strong belief in the religion they hold. This belief is guided by Muslims needing to have a sharia-based banking mechanism that imposes various restrictions to avoid receiving interest rates or usury, gambling or gharar, and specific directives for the Islamic banking system (for example "PLS" or "profit and loss sharing agreements)" [8,26].

A study of competition in banking industry is related to some reasons. First reason that level of market power can affect the financial stability, where it shows that competitiveness can drive moral danger in the banking sector, especially in Asian countries. Second, competition conditions are responsible for influencing banking performance and efficiency, which shows that the relationship between competition and performance in the banking system is more complex than in other industries in Asian countries. To achieve the company's main objectives, we need performance evaluation methods that can be measured in various forms such as financial ratio analysis, comparative analysis, general size analysis, and Du Pont analysis $[9,36]$.

This research will broaden the investigation of the multi-country context within Asian countries, which can enhance the reader's knowledge of the analysis of issues that discuss the influence of sharia bank market forces on global financial stability. This study also contributes differently by using the Lerner index as a $m$ easure of competitiveness for the Islamic banking sector and explains its effect on g lobal financial stability. Then this study also analyzes the effect of the market power of Islamic banks on global financial stability which is the most important issue for banking regulation, especially in the context of the latest disruption in international financial markets.

\section{Literature Review}

\subsection{Syariah Banking}

The Islamic financial services industry consists of increasingly diverse institutions, including commercial banks, investment, joint insurance, and investment companies. Today, banks remain the core of the financial services industry in many countries because banks are responsible for most financial transactions. The rapid growth of Islamic banks at the international level requires the development of their financial institutions to provide support for the stability and performance of the Islamic financial industry. The establishment of these institutions is necessary to bring the design of the Islamic financial industry to a higher standard, international standards that they can compete on the international scene. There are three main arguments needed for these institutions: 1) the development of rules and principles that meet the needs of Islamic financial sharia in the form of accounting and auditing standards, regulatory rules for various types of institutions, business valuation methods, transparency of actions and codes of ethics; 2) mechanism for implementing rules and principles in terms of active monitoring and supervision; 3) coordination of rules and principles across countries, between market participants, standardsetting bodies, supervisory and supervisory bodies. Islamic finance is a fast-growing industry in terms of the estimated size and growth rates of assets held internationally under various Islamic financial institutions. Although this growth represents only a small portion of the global financial market (estimated at $1 \%-5 \%$ of the global share), the Islamic finance industry has experienced rapid growth rates in double digits every year in recent years (estimated at $10 \%-20 \%$ annual growth). A survey of global Islamic financial institutions shows that assets that meet shariah criteria rose from the US \$ 1,047 billion in 2010 to US \$ 3,041 billion in 2016.

The rapid growth and challenges faced in developing Islamic banking have triggered public 
policy issues including regulatory instruments and regulatory frameworks in several countries where Islamic banking operates. Banks are reluctant to use PLS instruments because of inherent risks such as additional monitoring costs and lack of market transparency [11,52]. Therefore, further growth and development of the Islamic financial system require a uniform regulation and legal framework that supports Islamic banking work programs. Unfortunately, the existing framework based on the Western banking model can create long-term difficulties for Islamic banks to operate efficiently. Theoretically, sharia-based banking, commonly known as sharia banking, differs from conventional banking systems at a greater level. Where specifically sharia-based banking prohibits the use of interest or usury, which is pillared by the profit and loss distribution mechanism (PLS) which is also known as Mudarabah. In terms of risk-sharing both in terms of liabilities and assets, previous research argues that all transactions must be supported by real economic transactions involving tangible assets [16]. In other words, Islamic bank assets and liabilities are integrated into the intention that the borrower shares profits and losses with the bank, which in turn shares profits and losses with depositors under the PLS paradigm.

Apart from the aforementioned prohibitions, sharia-based banking adheres to some restrictions or other guidelines such as sharia-based banking is not allowed to do speculation $[12,26]$ thus, it can be concluded that the conduct of a business related to its derivatives is also prohibited, such as restricting banks from conducting certain businesses related to products/activities that are prohibited in the Koran (eg alcohol, pork, gambling). The guideline used is that sharia-based banking recommends that all financial activities or transactions must involve real economic activities [20,33]. However, there is a fundamental problem for every bank that claims to be a bank with an Islamic banking system because of the use of inherent interest, both directly and indirectly in all financial activities of 'interest-free' operations [24,33]. The scholars in Islam are also more interested in choosing Islamic banking than conventional banking because of the role of PLS agreements which are the main factors that can be distinguished and considered for Muslims themselves.
Most prior research agrees to the need for a regulatory framework that encourages wider and transparent disclosure of information to strengthen accounting standards. General banking laws or specific laws relating to Islamic banks must define in detail the nature of these banks and their specific operational relationships with central banks and other conventional banks. The legal framework must contain provisions containing permits, permitted modes of financing, and the power to deal with compliance with laws and regulations. Besides, the law must state clearly that the central bank (or supervisory authority) has the authority and all the power needed to oversee Islamic banks and conventional banks.

\subsection{Banking Competition}

The ability to maintain and develop its shares in the market when faced with competition from other national or foreign companies can be defined as the market power of a company. In this context, the competitiveness of banks must be tackled at two levels: on the one hand, banks can vary various financial products and services. Where on the other hand, to maximize social surplus using competitive prices [29,39]. Two main approaches are mainly used in the literature to measure banking competition: structural and non-structural approaches. The structural approach evaluates competitiveness by investigating the size of market structures, for example is concentration. Worker concentration is at ool to measure competition based on the structure-behavior-performance (SCP) hypothesis which postulates that in a highly concentrated market. However, several studies have shown that the relationship between concentration and performance is not always positive, it can be concluded that concentration is not a reliable measure of competition [15,41].

As a consequence, any other paradigm referred to as the efficiency-structure (ES) hypothesis was introduced by [38]. These authors assert that a positive correlation between company efficiency and market concentration may be explained by recognizing that these companies has quality management, technology to reduce costs and efficient production and operating system that can increase their market share and increase 
concentration. By verifying the SCP and ES assumptions, [4,22] argues that the SCP assumptions are not supported. He stated that both ES assumptions and relative market power cannot explain the effect of efficiency and market control variables on profitability.

However, a few critics disagree with perception that structure is the most important indicator of competitiveness. In the opposite hand, supporters of the literature called the New Industrial Organization (NIO) such as [44], state that the strategies and behavior of each company have more influence than concentration to explain the condition of competitiveness. Also, the emergence related to the theory of contestability $[2,3]$ gave birth to a variety of non-structural competition indicators aimed at identifying company strategies. The non-structural approach measures competition without using explicit information from the market structure, but it focuses on estimating market forces obtained from the determined banks.

[25,27,37] introduce 'H-statistics' for quantitative tests of the competitive nature of the banking sector and its market power. The degree of competitiveness is acquired from the reduction in the form of the income equation, which is equal to the amount of input price elasticity of the company's total income regarding the price of their factors [17]. The $\mathrm{H}$ statistic additionally describes income derived from input prices among other factors [7,31]. The P-R model is usually used to analyze the competitiveness of the banking industry in several countries. However, there are some boundaries in this model; first, the P-R model assumes that banks offer unique products because they are considered financial intermediaries [19]. Second, this model requires an assumption in which all banks have the same cost function. Third, many recent studies are commonly characterized through overestimation of the level of competition duet to the fact they use the Panzar and Rosse models $[17,42]$.

The non-structural measure used in our study is the Lerner index. The Lerner index is a direct measure in measuring competition because it emphasizes the limitations of pricing power, which is a measure by which companies can increase their marginal prices beyond marginal costs $[5,45]$. One interesting and unique study from [51] investigates the conditions of competition in the global Islamic and conventional banking sector using a proxy spectrum for competition. In a sample of banks in 13 countries during 2000-2006, the consequences confirmed that Islamic banks have been less competitive than conventional banks.

From a slightly exceptional perspective, research conducted by $[28,46]$ found that Islamic banking shows better resilience in the initial stages of the financial crisis compared to conventional banking. However, at a 1 ater stage in 2009, Islamic banks failed to beat conventional banks in terms of profitability measures. This phenomenon become partly dealt with by Shamshad Akhtar in his 2009 speech in Rome, Italy. He explained that the resilience of the early stages of Islamic banking was due to the higher dependence of Islamic banking on the real estate sector and the limited ownership in equity-based transactions $[10,47]$.

\section{Methodology}

This studies uses qualitative and quantitative approaches. The research evaluation was expanded to explain the effect of these measures on global financial stability. Also, our study also studies the effect of the market power of Islamic banks on global financial stability which is an important issue for banking regulation. We examine the market power of Islamic and conventional banks in each country in Asia, then we use descriptive statistics to analyze the factors that affect the competitiveness of banks in the region.

\subsection{Lerner Index}

The Lerner Index is the step one taken that may be defined as direct market power. The Lerner index is describe as the difference between output prices and marginal costs associated with output prices and makes it possible to identify precisely the degree to which companies can push their marginal prices beyond marginal costs, which requires estimation of marginal product costs [5]. The Lerner Index indicator also refers to previous research. The Lerner index is measured by the following equation:

Lernerit ${ }^{=}$Pit-Mcit $/ P i$ 
Where Pit is the price of output. And MCit is the marginal cost of the total assets of bank $i$ at $t$. The measurement of marginal cost is derived by derived from the estimated translog cost function by total assets.

Based on s tudies from [14,21,51] prices are calculated using the following ratio:

\section{$\mathrm{P}=\underline{\text { Total income (interest income and others) }}$ Total assets}

The Lerner index value varies between 0 a nd 1 . The high value of this index approaches 1 where it shows a monopolistic situation but, when the Lerner index tends to 0 , the level of competition is very high. The Lerner Index $<0$ requires prices that are lower than marginal costs and is an indicator of the results of less than optimal banking behavior.

\subsection{Z-score}

In the second stage, we analyze the stability of Islamic and conventional banks through a combined model using the Z-score as a p roxy for banking stability. Developed by [13], the Z-score can be defined as an indicator of insolvency risk. Where these indicators are recorded as follows; $\mathrm{Z}=$ $(\mu+\mathrm{K}) / \alpha$ where $\mu$ is the average return on assets (ROA), K social capital as a p ercentage of total assets and the standard deviation of ROA as a proxy for profitability volatility. The Z-score is the opposite of the bankruptcy probability [35] where a higher Z-score means a decrease in risk and indicates that the bank is more stable and in good condition. Our estimates are as follows:

$z i t=\int($ Lernerit $+C i t+T i+\operatorname{Ln}($ GDPper cota $))$

Where $\mathrm{Z}$ refers to the stability of bank $\mathrm{i}$ at $\mathrm{t}$, as defined above, Lerner is a banking competitiveness index, Cit is a vector consisting of two categories of structural and banking specific variables. For structural variables, we consider IHH as a measure of the concentration of banking in each country. In this study, we use IHH which is obtained from the sum of the quadratic market shares of all banks based on total assets. Besides, we consider bank size, efficiency and diversification of income (diversified) as o ther variables. According to $[35,49]$, a high level of diversification can be reflected in the high value of these variables. This estimate also includes the Neperian logarithm of GDP per capita to control differences in economic development between countries. In this research we used panel data regression because we took into account the dimensions of the double fold: the temporal dimension on the hand dimension and the individual (bank) dimension on the other hand. One of the main advantages of using panel data is to pay attention to the dimensions of the double fold. Also because our sample is quite weak due to the scarcity of data on Islamic banks, econometric panel data helps multiply the number of observations.

\section{Results and Discussion}

The panel data set was extracted from the nonconsolidated income and balance sheet reports of 79 conventional banks and 29 I slamic banks in 5 countries (Indonesia, Malaysia, Singapore, the Philippines, and Thailand). Financial data is converted into US dollars.

Table 1. Structure of Sample by Country and Type of Bank

\begin{tabular}{lll}
\hline Country & $\begin{array}{l}\text { Conventional } \\
\text { Banks }\end{array}$ & $\begin{array}{l}\text { Islamic } \\
\text { Banks }\end{array}$ \\
\hline Indonesia & 37 & 6 \\
Malaysia & 12 & 15 \\
Singapore & 3 & 6 \\
Thailand & 11 & 1 \\
Philipina & 16 & 1 \\
\hline \hline
\end{tabular}

This table shows that the number of Islamic banks operating in the sample countries is lower than conventional banks, which reflects the embryonic stage of the Islamic financial industry. Table 2 shows descriptive statistics of capitalization, profitability, cost efficiency, liquidity and the performance of conventional bank loans (Panel A) and Islamic banks (Panel B). 
Table 2. Banking Descriptive Statistic (Conventional Bank)

\begin{tabular}{|c|c|c|c|c|c|c|}
\hline Country & & ROA & ROE & $\begin{array}{l}\text { Total } \\
\text { Assets }\end{array}$ & Total Equity & Total Loans \\
\hline \multirow[t]{4}{*}{ Indonesia } & mean & 1.1147059 & 7.143088235 & 107020.72 & 14023.2998 & 71549.80824 \\
\hline & standav & 2.2135148 & 16.42439216 & 200171.7 & 27366.76667 & 131086.6796 \\
\hline & $\min$ & -9.72 & -86.75 & 745.65 & 107.21 & 13.2 \\
\hline & $\max$ & 13.39 & 32.61 & 1038710 & 153370 & 676180 \\
\hline \multirow[t]{4}{*}{ Malaysia } & mean & 1.0396 & 12.39789474 & 203.68947 & 18.76791386 & 134.957193 \\
\hline & standav & 0.2435 & 3.55364136 & 180.68156 & 16.19616229 & 228.8731953 \\
\hline & $\min$ & 0.55 & 4.55 & 11.56 & 0.87703 & 8.07 \\
\hline & $\max$ & 1.47 & 22.99 & 735.96 & 70.47 & 485.74 \\
\hline \multirow[t]{4}{*}{ Singapore } & mean & 1.03 & 11.98 & 364.710 & 34.46 & 217.46 \\
\hline & standav & 0.13 & 1.99 & 67.820 & 6.34 & 47.00 \\
\hline & $\min$ & 0.87 & 9.79 & 252.900 & 25.27 & 144.03 \\
\hline & $\max$ & 1.39 & 17.83 & 481.570 & 46.97 & 305.41 \\
\hline \multirow[t]{4}{*}{ Thailand } & mean & 1.19 & 12.29 & 1337.71 & 143.08 & 923.48 \\
\hline & standav & 0.52 & 4.91 & 1062.96 & 119.90 & 698.47 \\
\hline & $\min$ & -0.21 & -2.34 & 122.43 & 14.17 & 86.25 \\
\hline & $\max$ & 2.36 & 21.54 & 2940.00 & 379.24 & 2030.00 \\
\hline \multirow[t]{4}{*}{ Philippine } & mean & 1.38 & 11.13 & 473.78 & 53.55 & 247.81 \\
\hline & standav & 0.75 & 7.81 & 577.55 & 58.99 & 329.93 \\
\hline & $\min$ & -0.17 & -0.18 & 0.10 & 0.10 & 0.83 \\
\hline & $\max$ & 3.56 & 59.75 & 2320.00 & 217.54 & 1480.00 \\
\hline
\end{tabular}

Table 3. Banking Descriptive Statistic (Islamic Bank)

\begin{tabular}{|c|c|c|c|c|c|c|}
\hline Country & & ROA & ROE & $\begin{array}{l}\text { Total } \\
\text { Assets }\end{array}$ & $\begin{array}{l}\text { Total } \\
\text { Equity }\end{array}$ & $\begin{array}{l}\text { Total } \\
\text { Loans }\end{array}$ \\
\hline \multirow[t]{4}{*}{ Indonesia } & mean & 0.339828 & 2.240728 & 1195687 & 160543.1 & 24465.020 \\
\hline & $\begin{array}{l}\text { std } \\
\text { dev }\end{array}$ & 2.259728 & 26.07106 & 2682804 & 366051.3 & 16561.709 \\
\hline & $\min$ & -11.1444 & -132.525 & 4052.701 & -19649 & 2581.8825 \\
\hline & $\max$ & 2.63 & 26.23 & 9158061 & 1203016 & 57977.439 \\
\hline \multirow[t]{4}{*}{ Philippine } & mean & 7.45 & 12.526 & 13380154.7 & 6303808.51 & 3330171 \\
\hline & $\begin{array}{l}\text { std } \\
\text { dev }\end{array}$ & 4.65824 & 6.63267894 & 1090949.53 & 1216243.34 & 593292.2 \\
\hline & $\min$ & 3.18 & 6.41 & 11905165.3 & 4534199.57 & 2489572 \\
\hline & $\max$ & 7.45 & 12.526 & 13380154.7 & 6303808.51 & 3330171 \\
\hline \multirow[t]{4}{*}{ Singapore } & mean & 0.98388 & 10.76493 & 365103.9 & 33901.57 & 160167.5 \\
\hline & $\begin{array}{l}\text { Std } \\
\text { dev }\end{array}$ & 0.56359 & 5.518621 & 217284 & 20060.18 & 96996.93 \\
\hline & $\min$ & 0.00916 & 0.09842 & 23151.49 & 2443.254 & 14345.22 \\
\hline & $\max$ & 2.59979 & 25.72387 & 765302 & 75184 & 323099 \\
\hline \multirow[t]{4}{*}{ Malaysia } & mean & 0.45123 & 11.62442 & 465132 & 123542 & 25453.020 \\
\hline & $\begin{array}{l}\text { Std } \\
\text { dev }\end{array}$ & 0.36542 & 5.518621 & 317284 & 366051.3 & 15631.32 \\
\hline & $\min$ & 0.00821 & 0.09842 & 13151.49 & -15632 & 2534.2425 \\
\hline & Max & 2.35113 & 22.5637 & 565302 & 11216 & 4523.439 \\
\hline \multirow[t]{4}{*}{ Thailand } & Mean & 0.467 & 9.6575 & 8209160 & 4265566 & 2010223 \\
\hline & $\begin{array}{l}\text { Std } \\
\text { dev }\end{array}$ & 0.491 & 6.3632 & 996839 & 458694 & 883500 \\
\hline & Min & -0.496 & 0.6744 & 12893038.2 & 6654435.49 & 2375473.9 \\
\hline & Max & 1,855 & 24.563 & 14802274.2 & 7571729.63 & 4098115.9 \\
\hline
\end{tabular}

Garas (2017) describes that Islamic financial institutions face two types of challenges, namely internal and external challenges. Internal challenges can be used to engage customers using conventional banking products, and external challenges can be used to meet international transaction requirements because of a lack of Islamic regulatory systems. Sharia-based knowledge and training are needed to communicate Islamic banking products in order to penetrate international markets and increase local potential. The application of sharia principles and the implications of sharia banking products are analyzed through collaborative research from Shariah scholars and researchers [23]. Whereas other explains that Islamic banking must utilize the expertise of Islamic scholars to analyze problems in financing local and international businesses related to the Islamic system.

The share of banking (investment) in the market increased by $15 \%$ per year in the world in the last decade. The core thinking behind the rapid growth of Islamic banking is the element of the interestfree system $[18,32,34,43]$. The nature of Islamic banking is different from conventional banking, where Islamic banks have a moderate impact on the business sector because they follow a system similar to the traditional one and are regulated by the State Bank.

The ratio of equity to total assets in table 2 is always higher for Islamic banks, indicating that Islamic banks are better capitalized compared to their conventional counterparts. Banking regulations that impose more requirements on equity for the establishment of Islamic banks compared to conventional ones may be the cause of better-capitalized Islamic banks. Regarding profitability measures, the average ROA of Islamic and conventional banks, respectively, was $2.418 \%$ and $1.729 \%$, while the percentage corresponding to ROE was $14.29 \%$ and $14.14 \%$. This explains that Islamic banks can generate profits and be able to strengthen their position before conventional banks. Some reserachs argue that better socio-economic conditions and a better legal system are determinants for a better profitability of Islamic banks in ASEAN.

In this research, we have analyzed the ratio of costs to income as an indicator of efficiency that 
measures general expenditure from turnover. This ratio is an average of $58.59 \%$ for Islamic banks and $43.84 \%$ for conventional ones, where the higher value of this ratio reflects the lower level of cost efficiency which means the level of cost efficiency is higher in conventional banks because of the lower ratio. [54] investigated the efficiency of Islamic banks during 2002-2007. The asset quality analysis of the two types of banks shows that the ratio of loans to total assets in Islamic and conventional banks is $46.02 \%$ and $51.39 \%$, which indicates that these conventional banks allocate a greater share of their assets to loans and therefore they have a higher level of credit risk compared to Islamic banks.

Table 4 contains a comparison of the Herfindhal-Hirschman Index based on total assets, deposits and credit between Islamic and conventional banks. Based on these results, we note that the concentration in Islamic banks is three times higher than in conventional banks.

Table 4. Herfindahl-Hirschman Index by Total Assets, Deposits and Credits

\begin{tabular}{lllllll}
\hline \hline & \multicolumn{2}{c}{ Assets } & \multicolumn{2}{c}{ Deposits } & \multicolumn{2}{c}{ Loans } \\
& & & & & \\
\hline Country & IB & CB & IB & CB & IB & CB \\
\hline Indonesia & 0.340 & 0.504 & 0.682 & 0.435 & 0.732 & 0.54582 \\
Malaysia & 0.451 & 0.427 & 0.731 & 0.349 & 0.542 & 0.58966 \\
Singapore & 0.987 & 0.556 & 0.462 & 0.603 & 0.427 & 0.46272 \\
Thailand & 0.467 & 0.227 & 0.261 & 0.250 & 0.284 & 0.45492 \\
Philippine & 0.908 & 0.516 & 0.249 & 0.142 & 0.249 & 0.2986 \\
Average & 0.631 & 0.446 & 0.477 & 0.356 & 0.447 & 0.470 \\
\hline \hline
\end{tabular}

Table 5. Evolution of the Islamic and Conventional Banks Market Power during 2012- 2017

\begin{tabular}{lll}
\hline \hline Year & Islamic Bank & Conventional bank \\
\hline $\mathbf{2 0 1 3}$ & 0.3911 & 0.5993 \\
$\mathbf{2 0 1 4}$ & 0.3830 & 0.6248 \\
$\mathbf{2 0 1 5}$ & 0.4437 & 0.6368 \\
$\mathbf{2 0 1 6}$ & 0.4197 & 0.6470 \\
$\mathbf{2 0 1 7}$ & 0.4015 & 0.6462 \\
\hline \hline
\end{tabular}

Our research rejects the assumption that Islamic banks have greater market power and therefore have higher pricing power. Our assumptions are based on a fact that Islamic bank customers have a religious motivation, which means they are less sensitive to their prices and demands. Based on research conducted and published by Laurent Weill in matters of Islamic finance, two explanations lead to this result.

Several obligations that limit the activities of Islamic banks, such as halal investment principles, prohibitions on speculation and enforcement of fair price practices, can contribute to the minimization of the market power of Islamic banks. Then, the next explanation arises from the principle of profit sharing and loss sharing. Based on this principle, depositors in Islamic banks can be considered as shareholders by the way he does not receive a fixed interest rate, but rather they share the bank's share and profits. Higher profits come from services provided and are billed to depositors at a higher price paid by them. As a result, these depositors have an incentive to limit the cost of financial services performed by Islamic banks to their clients.

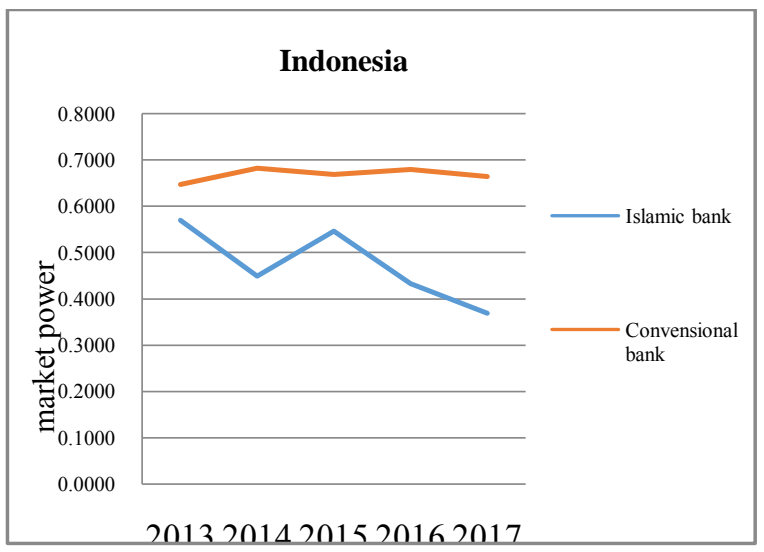

Fig. 1. Financial Performance of Indonesia Banks

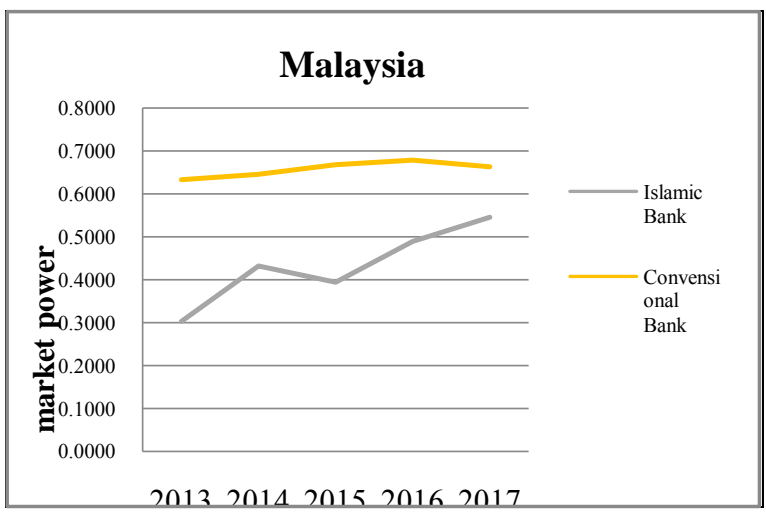

Fig.2. Financial Performance of Malaysia Banks 


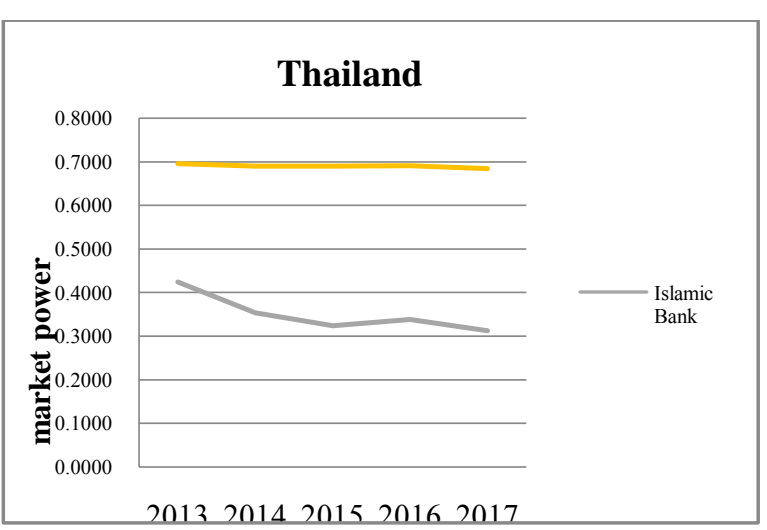

Fig.3. Financial Performance of Thailand Banks



Fig.4. Financial Performance of Philippine Banks

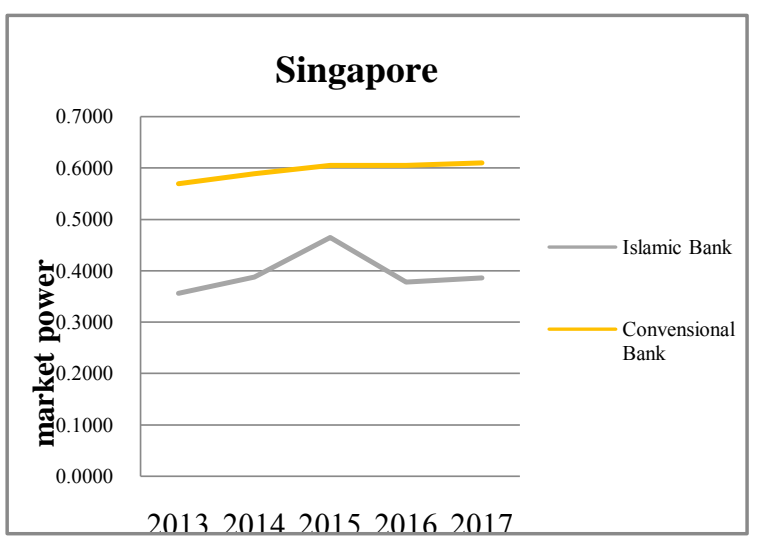

Fig.5. Financial Performance of Singapore Banks

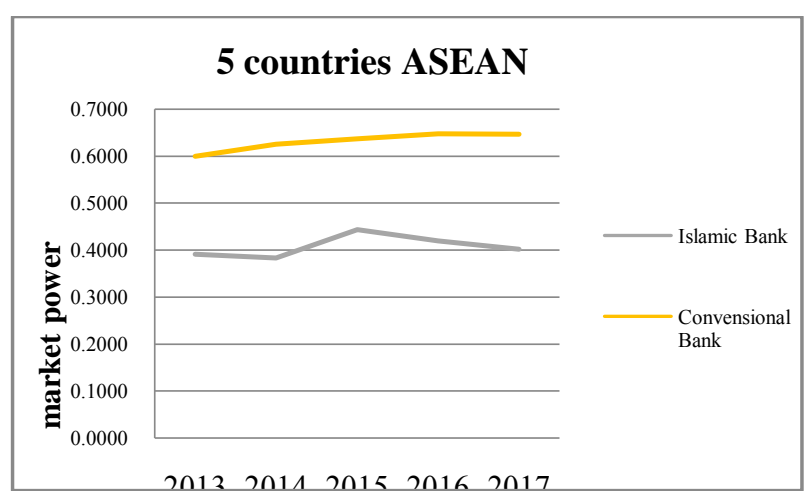

Fig.6. Financial Performance of ASEAN countries Banks
In Table 6 the estimation results of equation (3) show that the Lerner index is significantly and positively related to the Z-score, which confirms that the decline in banking competitiveness increases stability. This result is consistent with the 'franchise value' theory with the assumption that limited competitiveness can encourage banks to protect the value of their high franchises by pursuing security policies that contribute to the stability of the banking system. Based on the franchise principle, banks moderate their risk when they have an annuity, that when they gain market power. The banking literature empirically and theoretically supports this theory.

Table 6. Estimation Result

\begin{tabular}{ll}
\hline $\begin{array}{l}\text { Explanatory } \\
\text { variables }\end{array}$ & Z-score \\
\hline Size & $-0.431994^{*}$ \\
& $(0.064)$ \\
Efficiency & -0.0001211 \\
& $(0.313)$ \\
Diver & -1.131121 \\
& -0.182 \\
HHI & 2.912132 \\
& -0.262 \\
Lerner & 3.875361 \\
& -0.001 \\
Income & -9.655212 \\
diversity & -0.002 \\
& -1.000121 \\
Ln GDP & -0.021 \\
& 32.71312 \\
Constant & 0.000 \\
Observation & 820 \\
R-squared & 0.0731 \\
\hline \hline
\end{tabular}

However, the relationship between the measured concentration with $\mathrm{IHH}$ and financial stability is not significant, which confirms that the size of competitiveness is inadequate. As for certain banking variables, it was found that bank size negatively influenced the Z-score. Our results are consistent with most of the previous research which argues that several large banks face a higher level of risk. The efficiency coefficient of income diversity does not appear to be significant and the 
presence of Islamic banks in the banking system does not influence on the stability of conventional banks. Regression shows that Islamic banks are less stable than conventional banks because the principle of profit or risk sharing is characterized by negative and significant dummy variables of Islamic banks at the 5\% level.

\section{Conclusions}

This research compares descriptive analysis to show differences in composition between Islamic and conventional bank assets and portfolios. The results of the analysis of this research suggest that Islamic banks have a higher level of capitalization than conventional banks and therefore have a lower level of financial risk. Conventional banks are more vulnerable to credit risk due to the allocation of most of their assets to loans.

In this research, we observe the condition of competitiveness using the Lerner index and reject the initial assumptions that Islamic banks have greater market power. The results of the research are consistent with [53] who argues that adhering to certain religious principles and limits may be responsible for minimizing the market power of Islamic banks in Asia.

The second part of this research is that we use a parametric techniques to analyze the effect of market forces on the Z-score. The results are consistent with the theory of franchise value which postulates that limited competitiveness can encourage banks to maintain high franchise values from their security policies.

\section{References:}

[1] Allen, F. and Gale, D., Financial Contagion, Journal of Political Economy, Vol. 108, 2000, pp.1-33.

[2] Baumol, J.W., John, C.P. and Robert, D.W., Contestable Markets and the Theory of Industry Structure, 1982, Harcourt Brace Jovanovich, San Diego.

[3] Baumol, W., Contestable market: an uprising in the theory of industry structure, The American Economic Review, Vol. 72, No. 1, 1982, pp.115.

[4] Berger, A.N., The profit-structure relationship in banking: tests of market power and efficient-structure hypotheses, Journal of Money, Credit, and Banking, Vol. 27, No. 2, 1995, pp.404-431.

[5] Berger, A.N., Klapper, L.F. and Turk Ariss, R., Bank competition and financial stability', Journal of Financial Services Research, Vol. 35, 2009, pp.99-118

[6] B erger, N.A., Demirguc-Kunt, A., Levine, R.A. and Haubrich, J., Bank concentration and competition: an evolution in the making', Journal of Money, Credit and Banking, Vol. 36, 2004, pp.433-451.

[7] Bikker, J., Spierdijk, L. and Finnie, P., Misspecification of the Panzar-Rosse Model: Assessing Competition in $\mathrm{t}$ he Banking Industry, DNB Working Paper, No. 114, 2006, De Nederlandsche Bank.

[8] Boot, A.W.A. and Thakor, A., Can relationship lending survive competition?, Journal of Finance, Vol. 55, 2000, pp.679-713.

[9] Boumediene, A. and Caby, J., The Stability of Islamic Banks during the Subprime Crisis, 2009.

[10] Bourkhis, K. and Nabi, S., Islamic and conventional banks' soundness during the 2007-2008 financial crisis, Review of Financial Economics, Vol. 22, 2013, pp.6877.

[11] Boyd, J. and De Nicolo, G., The theory of bank risk taking revisited, Journal of Finance, Vol. 60, 2005, pp.1329-1343.

[12] Boyd, J.H. and Graham, S.L., Risk, regulation and bank holding company expansion into nonbanking, Federal Reserve Bank of Minneapolis Quarterly Review, Vol. 2, 1986, pp.2-17.

[13] Boyd, J.H. and Graham, S.L., The profitability and risk effects of allowing bank holding companies to merge with other financial firms: a simulation study, Federal Reserve Bank of Minneapolis Quarterly Review, Vol. 2, 1988, pp.3-20.

[14] Carbo, S., Humphrey, D., Maudos, J. and Molyneux, P., Cross-country comparisons of competition and pricing power in European Banking, Journal of International Money and Finance, Vol. 28, 2009, pp.115-134.

[15] Cetorelli, N., Competitive analysis in banking: appraisal of the methodologies, Economic Perspectives, 1999, pp.2-15.

[16] Cihak, M. and Hesse, H., Islamic Banks and Financial Stability: An Empirical Analysis, Working Papers No. 08/16, IMF, 2008. 
[17] Claessens, S. and Laeven, L., What drives bank competition? Some international evidence, Journal of Money, Credit and Banking, Vol. 36, No. 3, 2004, pp.563-583.

[18] Dar, A., On Explaining the Differences in Economic Growth Rates in OECD Countries. Ekonomia, 6(2), 2003, 147-159.

[19] De Bandt, O. and Davis, E.P., Competition, contestability and market structure in European banking sectors on the eve of EMU, Journal of Banking and Finance, Vol. 24, 2000, pp.1045-1066.

[20] De Guevara, F., Maudos, J.J. and PWrez, F., Integration and competition in the European financial markets, Journal of International Money and Finance, Vol. 26, 2007, pp.26-45.

[21] De Guevara, F., Maudos, J.J. and Perez, F., Market power in European banking sector,Journal of Financial Services Research, Vol. 27, No. 2, 2005, pp.109-137.

[22] Demsetz, H., Industry structure, market rivalry, and public policy, Journal of Law and Economics, Vol. 16, 1974, pp.1-9.

[23] El-Din, S. I. T., \& Abdullah, N. I ., Issues of implementing Islamic hire purchase in dual banking systems: Malaysia's experience. Thunderbird International Business Review, 49(2), 2007, 225-249.

[24] Fungacova, Z., Solanko, L. and Weill, L., Market power in the Russian banking industry, Bank of Finland Discussion Papers, No. 3, 2010, pp.1-27.

[25] Gamaginta, D. and Rokhim, R., The stability comparison between Islamic banks and conventional banks: evidence in I ndonesia, Paper presented at the Proceedings of the 8th International Conference on Islamic Economics and Finance, 19-21 December, 2011, Doha, Qatar.

[26]Gheeraert, L., Does Islamic finance spur banking sector development? Journal of economic behavior \& organization, 2014, 103, S4-S20.

[27] Hasan, I. and Marton, K., Development and efficiency of a banking sector in a transitional economy: Hungarian experience, Journal of Banking and Finance, Vol. 27, 2003, pp.2492271.

[28] Hasan, M. and Dridi, J., The Effects of the Global Crisis on Islamic and Conventional Banks: A Comparative Study, Working Papers, No. 10/201, IMF, 2010.
[29] Hellman, T.F., Murdock, K. and Stiglitz, J., Liberalization, moral hazard in banking and prudential regulation: Are capital requirements enough?, American Economic Review, Vol. 90, 2000, pp.147-165.

[30] Iqbal, M. M. P., Thirty years of Islamic banking: History, performance, and prospects, 2005.

[31] Jackson, W., The price-concentration relationship in banking: a comment, Review of Economics and Statistics, Vol. 74,. 1992 , pp.373-376

[32] Khan, M. S., Islamic interest-free banking: a theoretical analysis. Staff Papers, 33(1), 1986, $1-27$.

[33] Khan H. U. Z., The effect of corporate governance elements on corporate social responsibility (CSR) reporting: Empirical evidence from private commercial banks of Bangladesh. International Journal of Law and Management, 52(2), 2010, 82-109.

[34] Khan, M. A. Mirakhor, Theoretical Studies in Islamic Banking and Finance, 1987.

[35] Laeven, L., \& Levine, R., Bank governance, regulation and risk taking. Journal of financial economics, 93(2), 2009, 259-275.

[36] Laksana, R.D., Hersugondo, Does Economic Value Added Influence The Shareholder Value In Indonesia?. International Journal of Applied Business and Economic Research, 2016.

[37] Panzar, J. C., \& Rosse, J. N., Testing for" monopoly" equilibrium. The journal of industrial economics, 1987, 443-456.

[38] Peltzman, S., The gains and losses from industrial concentration, Journal of Law and Economics, Vol. 20, 1977, pp.229-263

[39] Rajhi, T. and Salah, H., Concurrence et compétitivité bancaire en Algérie: Econométrie de panels sur la période 20002007, African Development Review, Vol. 23, No. 1, 2011, pp.16-29.

[40] Rehman, A. A., Customer satisfaction and service quality in Islamic banking. Qualitative Research in Financial Markets, 2012.

[41] Schaeck, K. and Cihak, M., Banking Competition and Capital Ratios, IMF Working Paper, IMF, Vol. 7, 2007, p.216.

[42] Schaeck, K., Cihak, M. and Wolfe, S., Are competitive banking systems more stable?, Journal of Money, Credit and Banking, Vol. 41, 2009, pp.711-734. 
[43] Schaeck, K., Čihak, M. and Wolfe, S., Are More Competitive Banking Systems More Stable?, Working Paper No. 06/143, IMF, 2006.

[44] Schmalensee, R., Inter-Industry Studies of Structure and Performance, Handbook of Industrial Organization, 1st ed., Vol. 2, Chapter 16, 1989, pp.951-1009.

[45] Shaferi, I., Laksana, R.D., and Wahyudi, S., The effect of risk leverage on investors' preferences in manufacturing companies listed on the Indonesia Stock Exchange. Investment Management and Financial Innovations, 15(3), 2018, 190-198.

[46] Soedarmon, W., Machrouh, F. and Tarazi, A. , Bank market power, economic growth and financial stability: evidence from Asian banks, Journal of Asian Economics, Vol. 22, 2011, pp.460-470.

[47] Stiglitz, E.J. and Weiss, A., Credit rationing in markets with imperfect information, American Economic Review, Vol. 71, 1981, pp.393-410.

[48] Sun, L. and Chang, T-P., A c omprehensive analysis of the effects of risk measures on bank efficiency: evidence from emerging Asian countries, Journal of Banking and Finance, Vol. 35, 2011, pp.1727-1735.

[49] Tabak, M.B., Fazio, M.D. and Cajueiro, O.D., The relationship between banking, 2012.

[50] Thambiah, S., Eze, U. C., Tan, K. S., Nathan, R. J., \& Lai, K. P., Conceptual framework for the adoption of Islamic retail banking services in Malaysia. Journal of Electronic Banking Systems, Vol.1, 2010, 1-10.

[51] Turk Ariss, R., Competitive conditions in Islamic and conventional banking: a global perspective, Review of Financial Economics, Vol. 19, 2010, pp.101-108.

[52] Van Greuning, H., \& Iqbal, Z., Risk analysis for Islamic banks. The world bank., 2007.

[53] Weill, L., Do Islamic banks have greater market power?, Comparative Economic Studies, Vol. 53, 2011, pp.291-306.

[54] Xiaoqing, M.F., Yongjia, R.L. and Philip, M., Bank competition and financial stability in Asia Pacific, Journal of banking and finance, Vol. 38, 2014, pp.64-77. 